\title{
EFFECT OF VARIOUS PARAMETERS IN REMOVING Cr AND Ni FROM MODEL WASTEWATER BY USING ELECTROCOAGULATION
}

\section{VLACHOU M. HAHLADAKIS J. GIDARAKOS E.}

Received: $25 / 07 / 13$

Accepted: $16 / 09 / 13$

\author{
Department of Environmental Engineering, \\ Technical University of Crete, University Campus, \\ 73100, Chania, Greece
}

*to whom all correspondence should be addressed: e-mail: gidarako@mred.tuc.gr

\begin{abstract}
The performance of a laboratory scale electrocoagulation system for the removal of $\mathrm{Cr}$ and $\mathrm{Ni}$ from model wastewater was studied systematically using iron and aluminum electrodes with an effective surface area of $13.8 \mathrm{~cm}^{2}$ and a distance of $4 \mathrm{~cm}$. The influence of several parameters, such as initial concentration, electrode combination, current supply and initial $\mathrm{pH}$ was investigated during electrocoagulation process. The increase in initial concentration favored removal rate, did not affect nickel removal, but restricted chromium removal, thus indicating its required mechanism of reducing hexavalent ion to trivalent. The best removal efficiency, when metals existed separately in treated solutions, was accomplished with the use of iron electrodes for $\mathrm{Cr}(50 \%)$ and with aluminum electrodes for $\mathrm{Ni}(90 \%)$. When metals co-existed, iron electrodes achieved the best result, which was $76 \%$ for $\mathrm{Cr}$ and $82 \%$ for $\mathrm{Ni}$, leaving $30 \mathrm{mg} \mathrm{l}^{-1}$ and $17 \mathrm{mg} \mathrm{l}^{-1}$ of residual concentrations, respectively, after $180 \mathrm{~min}$ of treatment. Solutions' nominal $\mathrm{pH}$ appeared to be optimal, since increasing or decreasing their initial value did not benefit the electrocoagulation process. Chromium and nickel simultaneous removal was best achieved for conditions of $100 \mathrm{mg} \mathrm{I}^{-1}$ initial concentration, $\mathrm{pH} 5$ and a current of $0.8 \mathrm{~A}$.
\end{abstract}

KEYWORDS: electrocoagulation; heavy metals; chromium removal; nickel removal.

\section{INTRODUCTION}

Heavy metals' presence in industrial effluents is one of the most major toxic pollution factors, though inevitable, due to their wide range of applications. $\mathrm{Cr}(\mathrm{VI})$ is used in metallurgy, electroplating, leather tanning, chemical catalysts, pigments, corrosion inhibitors and printing inks, while $\mathrm{Ni}(\mathrm{III})$ in production of stainless steel, alnico magnets, coinage, rechargeable batteries, electric guitar strings, microphone capsules, and special alloys. Both are toxic to most living organisms and have a significant mobility in the environment through water cycle (EPA, 1998; Gerberding, 2005). Various techniques have been employed for the treatment of heavy metals, including chemical precipitation, ion-exchange, adsorption, biosorption, membrane filtration, coagulation-flocculation, flotation and electrodialysis as well as electrochemical methods (Fu and Wang, 2011).

Electrocoagulation (EC) is an electrochemical method which was developed to overcome the drawbacks of conventional treatment technologies and remove efficiently heavy metals from contaminated water and wastewater environments. It is a simple, reliable, and low cost method, which uses a direct current source supply between metal electrodes immersed in polluted water, without any need for additional chemicals, while at the same time reduces the amount of sludge that should be disposed (Holt et al., 2002; Mollah et al., 2004). EC has been sufficiently used so far in many applications of effluents treatment, such as oil-water emulsions (Öğütveren and Koparal, 1997), dye-containing solutions (Do and Chen, 1994; Lin and Peng, 1994) as well as urban and restaurant wastewaters (Chen et al., 2000). More recent studies have shown great capability of EC in cleaning highly polluted galvanic (Heidmann and Calmano, 2010) metal plating (Akbal and CamcI, 2012) tannery (Módenes et al., 2012) and hospital wastewater (Arsand et al., 2012). Moreover, it appears as a an efficient method in reducing dissolved organic or inorganic pollutants from gray 
water (Bani-Melhem and Smith, 2012) and groundwater (Mohora et al., 2012). In addition, several researchers used EC technique to purify drinking water (Vasudevan et al., 2011; Cataldo Hernández et al., 2012; Edris et al., 2012).

EC has been also applied in various cases in order to remove high concentrations of heavy metals. $\mathrm{Cr}(\mathrm{VI}), \mathrm{As}(\mathrm{III}), \mathrm{Cu}(\mathrm{II})$ and $\mathrm{Ni}(\mathrm{III})$ removal has been investigated so far under several initial concentrations, different combinations of electrodes (iron, aluminium) and various experimental conditions of $\mathrm{pH}$ and current density (Heidmann and Calmano, 2008a; b; Thella et al., 2008; Aber et al., 2009; Bhatti et al., 2009; Zongo et al., 2009; Heidmann and Calmano, 2010; Akbal and Camcı, 2011; Hanay and Hasar, 2011; Keshmirizadeh et al., 2011), in order to determine the optimal conditions for efficient operation of the relevant system. They all demonstrated successful treatment of aqueous solutions and concluded that metal removal increased with increasing current density, $\mathrm{pH}$ and conductivity. However, they provide little insight into fundamental chemical and physical mechanisms, which according to the author's knowledge need to be further investigated.

In this study an electrocoagulation device was optimized to treat different model solutions with $\mathrm{Cr}(\mathrm{VI})$ and $\mathrm{Ni}(\mathrm{III})$ at relatively high initial concentrations. The parameters examined were: initial metal concentration, iron and aluminum electrode combination, applied current and initial $\mathrm{pH}$. As for the experimental data, total metal removal, removal rate and sacrificial anode's mass loss were calculated, in order to evaluate the method, determine the influencing factors and examine the feasibility of electrocoagulation under certain conditions.

\section{MATERIALS AND METHODS}

\section{Theory behind electrocoagulation process}

Electrocoagulation is a complicated process, as it involves many chemical and physical phenomena during consumable electrodes' dissolution for coagulating ions production. It is based on the in situ formation of the coagulant as the sacrificial anode corrodes due to an applied current, while the simultaneous evolution of hydrogen at the cathode allows pollutant removal. When a potential is applied from an external power source, the anode material undergoes oxidation, while the cathode is subjected to reduction or reductive deposition of elemental metals (Heidmann and Calmano, 2008a; Hanay and Hasar, 2011). The three successive stages of EC process are (Mollah et al., 2004):

(i) formation of coagulants by electrolytic oxidation of the 'sacrificial electrode'

(ii) destabilization of the contaminants, particulate suspension, and breaking of emulsions

(iii) aggregation of the destabilized phases to form flocs.

The main reactions occurring at the anode are dissolution of iron or aluminum (oxidation) and water electrolysis:

$\mathrm{Fe}_{(\mathrm{s})} \rightarrow \mathrm{Fe}^{2+}{ }_{(\mathrm{aq})}+2 \mathrm{e}^{-}$

$\mathrm{Al}_{(\mathrm{s})} \rightarrow \mathrm{Al}^{3+}{ }_{(\mathrm{aq})}+3 \mathrm{e}^{-}$

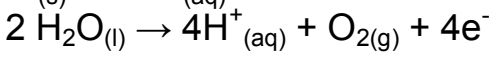

It is generally assumed that iron is dissolved as $\mathrm{Fe}^{2+}$ (Barrera-Díaz et al., 2003; Gao et al., 2005; Heidmann and Calmano, 2010). The main reactions occurring at the cathode are water electrolysis and direct electrochemical metal reduction:

$\mathrm{Fe}^{2+}+2 \mathrm{e}^{-} \rightarrow \mathrm{Fe}$

$\mathrm{Al}^{3+}+3 \mathrm{e}^{-} \rightarrow \mathrm{Al}$

$2 \mathrm{H}_{2} \mathrm{O}+2 \mathrm{e}^{-} \rightarrow \mathrm{H}_{2(\mathrm{~g})}+2 \mathrm{OH}^{-}$

Anodic metal ions and hydroxide ions generated at the electrode surfaces undergo immediately further spontaneous reactions in the bulk wastewater solution to form hydroxides, $\mathrm{Fe}(\mathrm{OH})_{2}, \mathrm{Al}(\mathrm{OH})_{3}$, and polymeric hydroxyl- complexes, namely: $\mathrm{Fe}\left(\mathrm{H}_{2} \mathrm{O}\right)_{6}{ }^{3+}, \mathrm{Fe}\left(\mathrm{H}_{2} \mathrm{O}\right)_{5}(\mathrm{OH})^{2+}, \quad \mathrm{Fe}\left(\mathrm{H}_{2} \mathrm{O}\right)_{4}(\mathrm{OH})_{3+}^{2^{++}}$, $\mathrm{Fe}_{2}\left(\mathrm{H}_{2} \mathrm{O}\right)_{8}(\mathrm{OH})_{2}{ }^{4+}, \mathrm{Fe}_{2}\left(\mathrm{H}_{2} \mathrm{O}\right)_{6}(\mathrm{OH})_{4}{ }^{4+}$ and $\mathrm{Al}(\mathrm{OH})^{2+}, \mathrm{Al}(\mathrm{OH})_{2}{ }^{+}, \mathrm{Al}_{2}(\mathrm{OH})_{2}{ }^{4+}, \mathrm{Al}(\mathrm{OH})_{4}{ }^{-}, \mathrm{Al}_{6}(\mathrm{OH})_{15}{ }^{3+}$, $\mathrm{Al}_{7}(\mathrm{OH})_{17}{ }^{4+}, \mathrm{Al}_{8}(\mathrm{OH})_{20}{ }^{4+}, \mathrm{Al}_{13} \mathrm{O}_{4}(\mathrm{OH})_{24}{ }^{7+}, \quad \mathrm{Al}_{13}(\mathrm{OH})_{34}{ }^{5+}$ for $\mathrm{Fe}$ and $\mathrm{Al}$ electrodes respectively, depending on the $\mathrm{pH}$ of the aqueous medium. The suspended aluminum or iron hydroxides can remove pollutants from the solution by sorption, precipitation or electrostatic attraction, followed by coagulation (Mollah et al., 2004).

Moreover, there are further reactions occurring in the bulk solution, which include heavy metal ions reduction and co-precipitation (Gao et al., 2005). 


$$
\begin{aligned}
& \mathrm{Cr}_{2} \mathrm{O}_{7}{ }^{2-}+6 \mathrm{e}^{-}+7 \mathrm{H}_{2} \mathrm{O} \rightarrow 2 \mathrm{Cr}^{3+}+14 \mathrm{OH}^{-} \\
& \mathrm{Cr}_{(\mathrm{aq})}{ }^{3+}+3 \mathrm{OH}^{-} \rightarrow \mathrm{Cr}(\mathrm{OH})_{3(\mathrm{~s})} \\
& \mathrm{Ni}_{(\mathrm{aq})}{ }^{2+}+2 \mathrm{OH}^{-} \rightarrow \mathrm{Ni}(\mathrm{OH})_{2(\mathrm{~s})}
\end{aligned}
$$

The hydroxide ions formed at the cathode increase the $\mathrm{pH}$ of the wastewater.

\section{Model wastewater characteristics}

Stock solutions of $2000 \mathrm{mg} \mathrm{l}^{-1} \mathrm{Cr}(\mathrm{VI})$ and $\mathrm{Ni}(\mathrm{II})$ were prepared by using $\mathrm{K}_{2} \mathrm{Cr}_{2} \mathrm{O}_{7}$ (Riedel-de Haën, $\geq 99.8 \%$ ) and $\mathrm{N}_{2} \mathrm{NiO}_{6} \cdot 6 \mathrm{H}_{2} \mathrm{O}$ (Flucka, $\geq 98.5 \%$ ), respectively. To examine the effect of initial metal concentration on the system performance, several samples were diluted $\left(100-500 \mathrm{mg} \mathrm{I}^{-1}\right)$ with constant current supply. The influence of $\mathrm{pH}$ was examined to ensure a better elimination of metal ions. The experiments were conducted with initial $\mathrm{pH}$ varying between values $3-7$, adding $\mathrm{H}_{2} \mathrm{SO}_{4}(5 \mathrm{~N})$ to acidify and $\mathrm{NaOH}(1 \mathrm{M})$ to increase it to 7 , at initial total metal concentrations of $200 \mathrm{mg} \mathrm{I}^{-1}$.

\section{Batch experiments}

Experiments were performed by using an ordinary 1-liter beaker, placed on a magnetic stirrer (Heidolph MR Hei-Standard) at $100 \mathrm{rpm}$. The pair of iron and/or aluminum electrodes (Erlikon SA Sidenor, General purpose electrode Fincord-M) were cylindrical $\left(D=3.25 \mathrm{~mm}, \mathrm{~L}_{\text {act }}=13.5 \mathrm{~cm}\right)$ and vertically installed in the beaker at a fixed distance of $4 \mathrm{~cm}$. A steady current was applied by a DC power supply (Statron, $0-300 \mathrm{~V}, 0-1.2 \mathrm{~A}$ ). The experimental set up is presented in Figure 1 . The experimental duration time was $3 \mathrm{~h}$, while samples were periodically taken from the bulk every 20 min, filtered $(0.45 \mu \mathrm{m})$, acidified $\left(290 \mu \mathrm{L} \mathrm{HNO}_{3} / 10 \mathrm{ml}\right.$, Fluka, Nitric acid Salpetersäure) and finally kept at $4^{\circ} \mathrm{C}$ until they were analyzed.

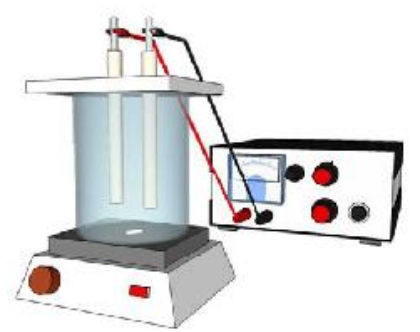

Figure 1. Experimental set up

\section{Measurements}

Initial conductivity of the solutions was measured before each experiment with a Crison CM 35 Conductivity meter and the $\mathrm{pH}$ of the samples with a Crison $\mathrm{pH}$-meter GLP21. $\mathrm{Cr}(\mathrm{VI})$ concentration was measured throughout treatments using the 1,5-diphenylcarbohidrazide method (AWWA 3500-Cr D colorimetric method) using a Shimadzu UVmini 240 spectrophotometer with the absorption readings obtained at 540 . The total amount of $\mathrm{Ni}$, and $\mathrm{Cr}$ in samples was measured by flame atomic absorption spectrophotometer (Perkin, Elmer A Analyst 100). Also, the anode electrode mass loss, which occurred during the process, was measured by means of material balance.

\section{Calculations}

The total heavy metal removal is calculated from the difference of the initial and final concentration of the sample. The removal rates in removed metal in $\mu \mathrm{mol}$ per inserted charge loading $\left(\mu \mathrm{mol} \mathrm{A} \mathrm{s}^{-1}\right)$ are calculated from the linear gradient between metal removal $\left(\mu \mathrm{mol} \mathrm{I}^{-1}\right)$ and charge loading $\left(\mathrm{A} \mathrm{s}^{-1}\right)$. Dissolution rate of the anode was calculated by weighing the electrode at the beginning and the end of the experiments, after rinsing it with deionised water and letting it to dry, in turn. This serves only for a rough comparison, because any formation of layers (i.e. hydroxides) during EC is not taken into consideration. The theoretically maximum dissolved mass of iron or aluminum, that occurs during EC process from the sacrificial anode for a specific electrical current flow in an electrolytic cell, is calculated according to Faraday's law (Mollah et al., 2004):

$$
\mathrm{m}=\frac{\mathrm{I} \cdot \mathrm{t} \cdot \mathrm{M}_{\mathrm{r}}}{\mathrm{z} \cdot \mathrm{F}}
$$


where $m$ is the amount of the dissolved anode material $(\mathrm{g}), \mathrm{I}$ the current $(\mathrm{A}), \mathrm{t}$ the electrolysis time $(\mathrm{s}), \mathrm{M}_{\mathrm{r}}$ the specific molecular weight of the anode electrode $(\mathrm{Fe}$ or $\mathrm{Al})\left(\mathrm{g} \mathrm{mol}^{-1}\right), \mathrm{z}$ the number of electrons involved in the reaction and $\mathrm{F}$ the Faraday's constant $\left(96485.34 \mathrm{~A} \mathrm{~s} \mathrm{~mol}^{-1}\right)$.

\section{RESULTS AND DISCUSSION}

\section{Effect of initial metal concentration}

Initial metal concentration effect was examined separately for $\mathrm{Cr}$ and $\mathrm{Ni}$ using both two $\mathrm{Al}$ electrodes and two Fe electrodes for each solution with a constant current of $0.5 \mathrm{~A}$. As illustrated in Figure 2, increasing the initial concentration of the metals, affects negatively the removal percentage. $\mathrm{Cr}$ maximum removal percentages $(50 \%$ for the total $\mathrm{Cr}$ and $67 \%$ for the $\mathrm{Cr}(\mathrm{VI}))$ were obtained when the lowest initial concentration (100 $\left.\mathrm{mg} \mathrm{l}^{-1}\right)$ was used and a Fe-Fe pair of electrodes. This substantial difference in the aforementioned percentages can be mainly attributed to the removal mechanism of chromium, as $\mathrm{Cr}(\mathrm{VI})$ is first reduced to $\mathrm{Cr}(\mathrm{III})$ and then removed. On the other hand, when Ni model solutions were treated, maximum removal percentage (88\%) was obtained at an initial concentration of $100 \mathrm{mg} \mathrm{l}^{-1}$, using an Al-Al electrode system. Nevertheless, initial concentration had little effect in $\mathrm{Ni}$ removal indicating, thereby, the nature of the removal mechanism (instantaneous) according to which $\mathrm{Ni}$ is converting directly to hydroxides and precipitates.

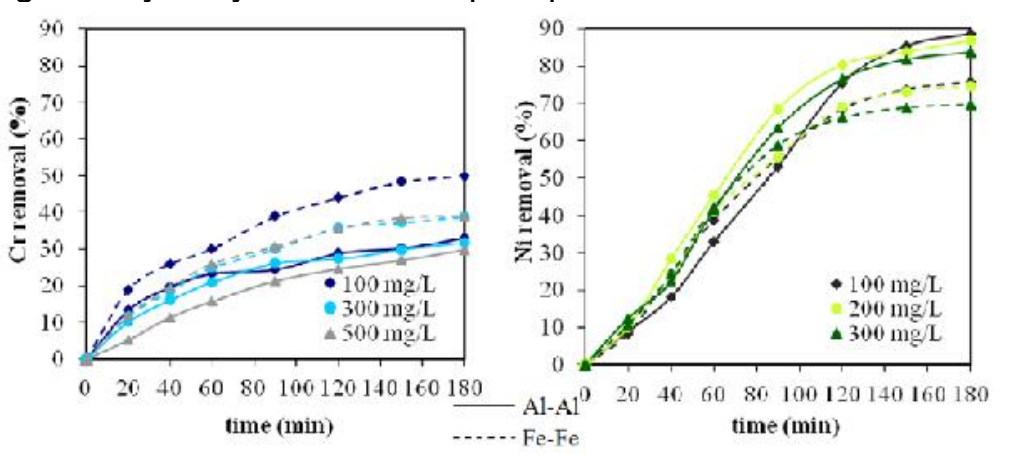

Figure 2. Effect of initial concentration of $\mathrm{Cr}$ and $\mathrm{Ni}$ on their total removal (\%) by using $\mathrm{Al}-\mathrm{Al}$ and $\mathrm{Fe}-$

Fe electrode system and applied current $0.5 \mathrm{~A}$

Removal efficacy of $\mathrm{Cr}$ decreased from $33 \%$ to $30 \%$ (using $\mathrm{Al}$ electrodes) and from $50 \%$ to $40 \%$ (using Fe electrodes) when initial concentration increased from 100 to $500 \mathrm{mg} \mathrm{l}^{-1}$, with respective conductivities of 200 and $1100 \mu \mathrm{S} \mathrm{cm}$, and an EC duration time of $180 \mathrm{~min}$. Similarly, removal efficacy of $\mathrm{Ni}$ varied from $88 \%$ to $84 \%$ (with Al electrodes) and between $75 \%$ to $70 \%$ (with $\mathrm{Fe}$ electrodes) with respective concentrations of 100 and $300 \mathrm{mg} \mathrm{I}^{-1}$ and conductivities ranging from 320 to $850 \mu \mathrm{S} \mathrm{cm}^{-1}$. The removal rate changes rapidly, at the beginning of the EC process, (up to $80 \mathrm{~min}$ for $\mathrm{Cr}$ and $120 \mathrm{~min}$ for $\mathrm{Ni}$ ) while afterwards the slope of the curve decreases (see Figure 2). At higher concentrations, the amount of sludge produced is not enough to absorb all the metal ions, thus causing decrease in their removal efficiency. Moreover, high concentrations increase the conductivity and the resistance of the solution, thereby leading to higher power consumption and lower metal removal (Heidmann and Calmano, 2008a; Thella et al., 2008).

Table 1 sums up the results for the removal rate of total $\mathrm{Cr}, \mathrm{Cr}(\mathrm{VI})$ and $\mathrm{Ni}$, as calculated from the slope of the linear relationship between the metal removal $(\mu \mathrm{mol})$ and the charge loading (As) on the basis of the experimental volume (1 litre). The rate is higher for higher metal concentrations, in all cases, a trend which can be attributed to the fact that the higher the heavy metals content in the solution is, the faster the reactions at the electrodes take place. In addition, $\mathrm{Cr}(\mathrm{VI})$ removal rate is higher than the total $\mathrm{Cr}$ rate, because $\mathrm{Cr}(\mathrm{VI})$ is first reduced to $\mathrm{Cr}(\mathrm{III})$, according to the removal mechanism, and consequently still measured at total $\mathrm{Cr}$ concentration. Furthermore, as it can be clearly seen from Table 1, Fe electrodes favour Cr removal, while Al electrodes Ni removal.

During the EC process, coagulants are produced through the formation of hydroxides while the $\mathrm{pH}$ of the solution increases with elapsed time, a trend shown in Figure 3.

Initial $\mathrm{pH}$ for all solutions, regardless of the initial concentration, was around 5 and as long as heavy metals were being removed, $\mathrm{pH}$ increased, till it reached a plateau value near the end of the process ( 8 for $\mathrm{Cr}$ and 9 for $\mathrm{Ni}$ ). This indicates the end of the reactions since hydroxides are not produced any more, thus the maximum level of removal has been accomplished under the certain conditions examined. 
Table 1. Initial and residual metal concentrations, metal removal and removal rates of $\mathrm{Cr}$ and $\mathrm{Ni}$ after 180 min of EC treatment with Fe-Fe and $\mathrm{Al}-\mathrm{Al}$ electrodes and $0.5 \mathrm{~A}$

\begin{tabular}{|c|c|c|c|c|c|c|}
\hline \multirow{2}{*}{$\mathrm{Cr}$} & \multicolumn{3}{|c|}{$\underline{F e-F e}$} & \multicolumn{3}{|c|}{$\underline{\mathrm{Al}-\mathrm{Al}}$} \\
\hline & & & & & & \\
\hline Initial concentration $\left(\mathrm{mg} \mathrm{l}^{-1}\right)$ & 100 & 300 & 500 & 100 & 300 & 500 \\
\hline Removal (\%) & & & & & & \\
\hline $\mathrm{Cr}$ (total) & 50 & 39 & 39 & 33 & 32 & 30 \\
\hline $\mathrm{Cr}(\mathrm{VI})$ & 67 & 55 & 51 & 37 & 36 & 35 \\
\hline Removal rate $\left(\mu \mathrm{mol} \mathrm{A}^{-1} \mathrm{~s}^{-1}\right)$ & & & & & & \\
\hline $\mathrm{Cr}$ (total) & 0.202 & 0.402 & 0.782 & 0.120 & 0.316 & 0.563 \\
\hline $\mathrm{Cr}(\mathrm{VI})$ & 0.274 & 0.580 & 1.014 & 0.150 & 0.369 & 0.667 \\
\hline $\mathrm{Ni}$ & & & & & & \\
\hline Initial concentration $\left(\mathrm{mg} \mathrm{I}^{-1}\right)$ & 100 & 200 & 300 & 100 & 200 & 300 \\
\hline Removal (\%) & 76 & 74 & 70 & 90 & 86 & 83 \\
\hline Removal rate $\left(\mu \mathrm{mol} \mathrm{A}^{-1} \mathrm{~s}^{-1}\right)$ & 0.257 & 0.511 & 0.717 & 0.303 & 0.598 & 0.818 \\
\hline Energy consumption $\left(\mathrm{kWh} \mathrm{m}^{-3}\right)$ & 18.0 & 20.3 & 21.0 & 12.0 & 12.8 & 14.3 \\
\hline
\end{tabular}

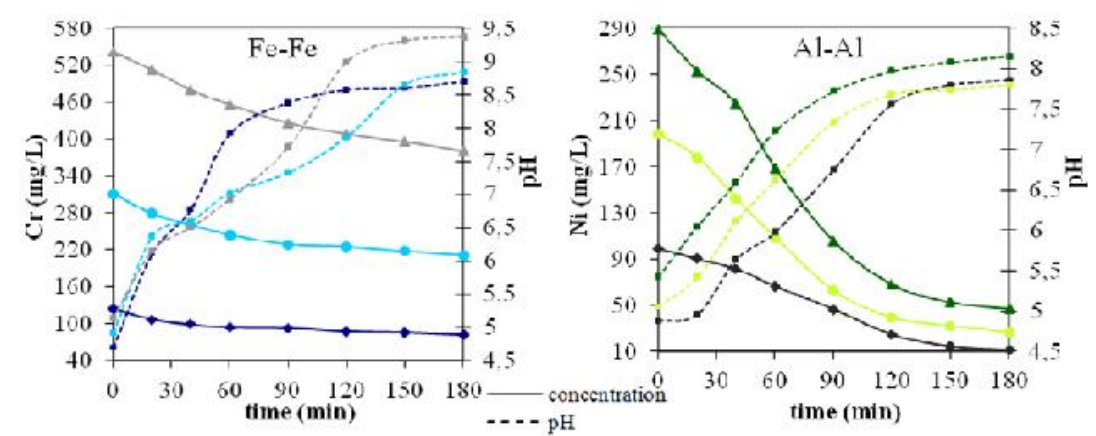

Figure 3. Concentrations of $\mathrm{Cr}$ and $\mathrm{Ni}$ along with $\mathrm{pH}$ values over electrocoagulation time for applied current $0.5 \mathrm{~A}$

\section{Effect of applied current}

In order to evaluate the effect of the applied current on the $\mathrm{EC}$ system, $\mathrm{Cr}$ and $\mathrm{Ni}$ solutions were treated separately at initial concentrations of $100 \mathrm{mg} \mathrm{l}^{-1}(\mathrm{pH}=5)$ using Al (currents: $0.2,0.5$ and $1.0 \mathrm{~A}$ ) and Fe electrodes (currents: 0.2, 0.5, $0.8 \mathrm{~A}$ ). Results for total removal and removal rates for each heavy metal are presented in Figure 4. The "\%" removal graphs show that by increasing the current supply the efficiency of the process is favoured. Fe-electrodes demonstrated better results when they were used for $\mathrm{Cr}$ stock solutions and Al-electrodes for Ni solutions, a trend also observed when initial concentration varied (section 3.1). Higher currents, as expected according to Faraday's law, led to higher ions production at the electrodes, vs. time, thereby enhancing the process. In a $\mathrm{Fe}-\mathrm{Fe}$ electrode system, under a $0.8 \mathrm{~A}$ current, the total $\mathrm{Cr}$ removal percentage obtained was $70 \%$ and the $\mathrm{Cr}(\mathrm{VI}) 78 \%$, leaving a residual concentration of approximately $30 \mathrm{mg} \mathrm{I}^{-1}$. On the other hand, $\mathrm{Ni}$ maximum removal efficiency reached almost $90 \%$ with an Al-Al electrode system, under a $1.0 \mathrm{~A}$ applied current, resulting in a residual concentration of $10 \mathrm{mg} \mathrm{l}^{-1}$.

More information on the efficiency of metal removal vs. current density is provided in the removal $\left(\mu \mathrm{mol} \mathrm{I} \mathrm{I}^{-1}\right)$ vs. charge loading $\left(\mathrm{A} \mathrm{s} \mathrm{I}^{-1}\right)$ diagrams. The removal rate of $\mathrm{Cr}$ at all cases appears to diverge from linear correlation. In the beginning of the experiments, more $\mathrm{Cr}$ was removed per ampere second than in the end, a fact which supports the aforementioned removal mechanism of reducing $\mathrm{Cr}(\mathrm{VI})$ to $\mathrm{Cr}(\mathrm{III})$ by the cathode. Moreover, the slope of the removal curves was higher when Fe-electrodes were used $\left(0.307-0.436 \mu \mathrm{mol} \mathrm{A}^{-1} \mathrm{~s}^{-1}\right)$ than with the use of Al-electrodes $(0.168-$ $0.300 \mu \mathrm{mol} \mathrm{A}^{-1} \mathrm{~s}^{-1}$ ), regardless the applied current. As for the removal rate of $\mathrm{Ni}$, it was constant at all cases, regardless the electrodes used and the slope of the curves remained constant under same applied currents, indicating the direct mechanism of its precipitation. 

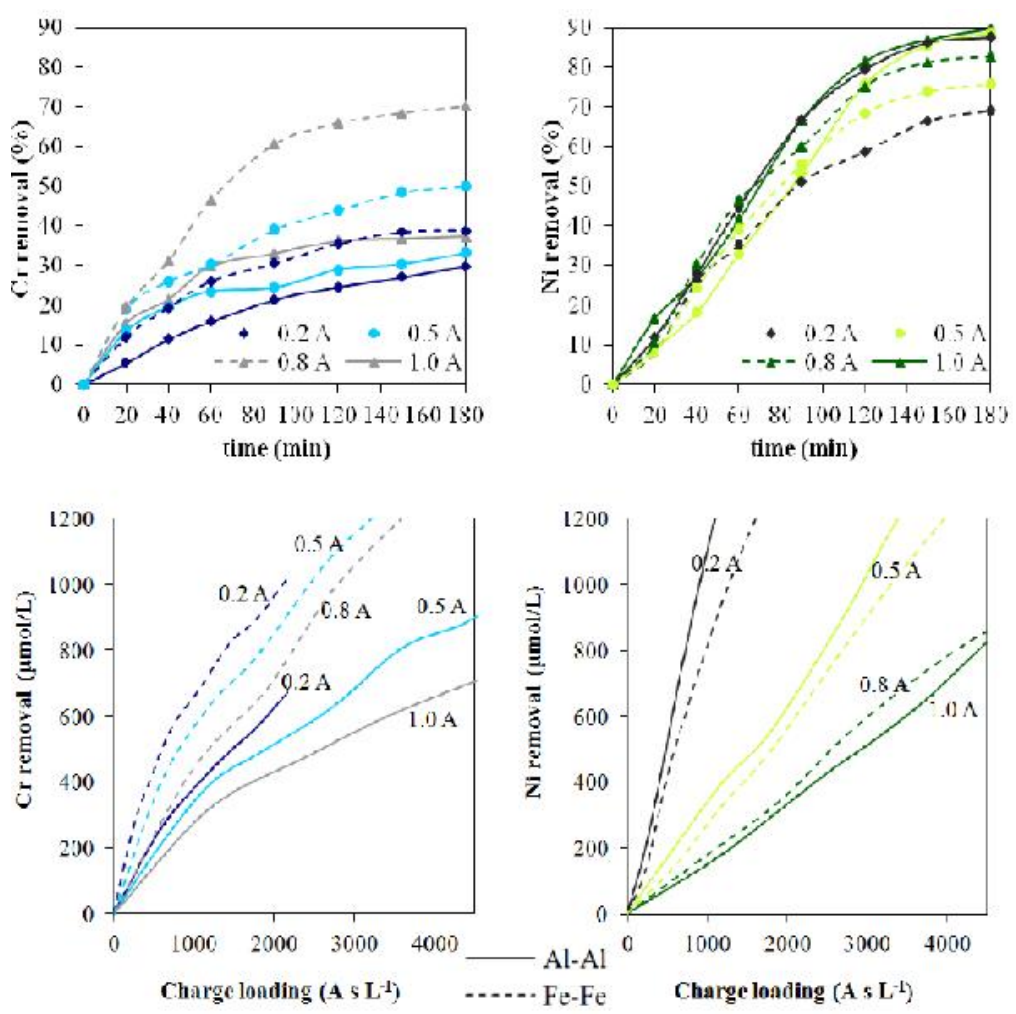

Figure 4. Effect of applied current on the total $\mathrm{Cr}$ and $\mathrm{Ni}$ removal and on removal rates by using $\mathrm{Al}-\mathrm{Al}$ and Fe-Fe electrode system and initial concentration $100 \mathrm{mg} \mathrm{I}^{-1}$

Fig. 5 shows the theoretical and experimental anode electrode's mass loss during a 180 min EC treatment of $\mathrm{Cr}$ and $\mathrm{Ni}$ model solutions under different applied currents. According to Faraday's law (eq. 8), the relationship between anode's mass loss and applied current is expected to be linear. When Al electrodes were used, experimental values were close to theoretical, however a differentiation at $1.0 \mathrm{~A}$ current for the $\mathrm{Ni}$ model solution treatment was observed, where the experimental loss was higher by $20 \%$. This can be attributed to the intense bubble formation which occurred at these experiments with high currents, as well as to the high removal rate, hence high dissolution of the sacrificial anode. Fe-electrode's mass loss appeared to be less than the theoretically expected (a 24\%-40 \% deviation), mainly because it did not cause high interaction with the heavy metals of the solution.
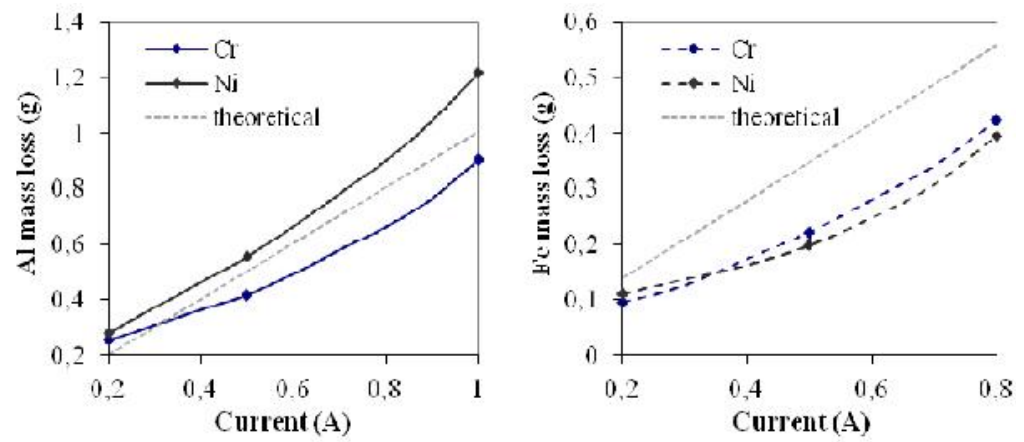

Figure 5. Comparison of the current effect on experimental and theoretical anode's mass loss

\section{Effect of electrode combination}

In an attempt to improve the already obtained heavy metal removal efficacy, all electrode combinations were tested (Fe-Fe, Fe-Al, Al-Fe and Al-Al) for a model solution spiked with both $\mathrm{Cr}$ and $\mathrm{Ni}$, of initial concentrations $100 \mathrm{mg} \mathrm{I}^{-1}$ for each metal and applied current of $0.8 \mathrm{~A}$. The results are illustrated in Table 2. For this solution, higher removal for both metals was achieved with a Fe-Fe electrode system. The second best results were obtained with a Fe-Al electrode system. This trend can be associated with the ability of the ferrous oxides to absorb in larger amounts the trivalent and hexavalent form of $\mathrm{Cr}$ and their hydroxyl ions (Akbal and Camcı, 2012). 
Table 2. Residual metal concentrations, metal removal and rates of $\mathrm{Cr}$ and $\mathrm{Ni}$, anode's mass loss, initial and final $\mathrm{pH}$ for different electrode arrangements after $180 \mathrm{~min}$ of EC of a solution with initial concentration $100 \mathrm{mg} \mathrm{l}^{-1}$ of each metal and $\mathrm{pH}=5$

\begin{tabular}{lcccc}
\hline & Fe-Fe & Fe-Al & Al-Fe & Al-Al \\
\hline Residual concentration $\left(\mathrm{mg} \mathrm{I}^{-1}\right)$ & & & & \\
Cr (total) & 30 & 63 & 86 & 70 \\
$\mathrm{Cr}(\mathrm{VI})$ & 28 & 51 & 70 & 88 \\
$\mathrm{Ni}$ & 17 & 38 & 20 & 10 \\
Removal (\%) & & & & \\
$\mathrm{Cr}$ (total) & 76 & 50 & 30 & 31 \\
$\mathrm{Cr}(\mathrm{VI})$ & 78 & 54 & 32 & 33 \\
$\mathrm{Ni}$ & 82 & 65 & 77 & 90 \\
Removal rate $\left(\mu \mathrm{mol} \mathrm{A}^{-1} \mathrm{~s}^{-1}\right)$ & & & & \\
$\mathrm{Cr}$ (total) & 0.179 & 0.126 & 0.072 & 0.066 \\
$\mathrm{Cr}(\mathrm{VI})$ & 0.194 & 0.129 & 0.066 & 0.185 \\
$\mathrm{Ni}$ & 0.166 & 0.145 & 0,147 & 0.080 \\
Anode's mass loss $(\mathrm{g})$ & 0.468 & 1.279 & 0.333 & 0.964 \\
End pH & 7.47 & 6.54 & 6.82 & 7.25 \\
Energy consumption $\left(\mathrm{kWh} \mathrm{m}^{-3}\right)$ & 32.4 & 28.8 & 30.0 & 33.6 \\
\hline
\end{tabular}

\section{Effect of initial pH}

As mentioned above, the $\mathrm{pH}$ of the medium rises during $\mathrm{EC}$ as a result of the electrochemical process and the production of hydroxyl ions in the aqueous stream, which remains as a gelatinous suspension. The initial $\mathrm{pH}$ effect was examined in a solution that contained $100 \mathrm{mg} \mathrm{I}^{-1} \mathrm{Cr}$ and 100 $\mathrm{mg}^{-1} \mathrm{Ni}(\mathrm{pH}=5)$ at a range of 3 to 7 , with the use of two Fe electrodes and applied current of $0.8 \mathrm{~A}$, for 180 min experimental duration time. Results indicated that varying the initial $\mathrm{pH}$ had negative effect in the EC procedure (Table 3). At initial $\mathrm{pH} 3$, the metals' removal was $40 \%$, with a final $\mathrm{pH}$ 6.65 , after 180 min of EC treatment and an anode's mass loss $40 \%$ lower than the theoretically expected. All the aforementioned observations are indications that EC process did not work properly in this case. Low $\mathrm{pH}$ did not favour hydroxides and hydroxyl ions formation and consequently inhibited the EC procedure, a phenomenon also reported by other researchers (Arroyo et al., 2009; Heidmann and Calmano, 2010). At initial $\mathrm{pH} 5$, the maximum removal achieved was $76 \%$ for $\mathrm{Cr}$ and $82 \%$ for $\mathrm{Ni}$, while final $\mathrm{pH}$ was 7.47 with an observed anode's mass loss near the theoretically expected (approximately 10\% less).

Table 3. Residual metal concentrations $\left(\mathrm{mg} \mathrm{l}^{-1}\right)$, metal removal $(\%)$, removal rates $\left(\mu \mathrm{mol} \mathrm{A}^{-1} \mathrm{~s}^{-1}\right)$ of $\mathrm{Cr}$ and $\mathrm{Ni}$, anode's mass loss and final $\mathrm{pH}$ for different initial $\mathrm{pH}$ after $180 \mathrm{~min}$ of $\mathrm{EC}$ of a solution with initial concentration $100 \mathrm{mg} \mathrm{l}^{-1}$ of each metal

\begin{tabular}{lccc}
\hline & $\mathbf{p H}=\mathbf{3}$ & $\mathbf{p H}=\mathbf{5}$ & $\mathbf{p H}=\mathbf{7}$ \\
\hline Residual concentration $\left(\mathrm{mg} \mathrm{l}^{-1}\right)$ & & & \\
$\mathrm{Cr}$ (total) & 73 & 30 & 85 \\
$\mathrm{Cr}(\mathrm{VI})$ & 72 & 28 & 90 \\
$\mathrm{Ni}$ & 58 & 17 & 52 \\
Removal (\%) & & & \\
$\mathrm{Cr}($ total) & 40 & 76 & 24 \\
$\mathrm{Cr}(\mathrm{VI})$ & 41 & 78 & 27 \\
$\mathrm{Ni}$ & 40 & 82 & 47 \\
Removal rate $\left(\mu \mathrm{mol} \mathrm{A}^{-1} \mathrm{~s}^{-1}\right)$ & & & \\
$\mathrm{Cr}($ total) & 0.112 & 0.179 & 0.063 \\
$\mathrm{Cr}(\mathrm{Vl})$ & 0.091 & 0.194 & 0.073 \\
$\mathrm{Ni}$ & 0.091 & 0.166 & 0.100 \\
Anode's mass loss $(\mathrm{g})$ & 0.326 & 0.468 & 0.257 \\
End pH & 6.65 & 7.47 & 9.21 \\
Energy consumption $\left(\mathrm{kWh} \mathrm{m}^{-3}\right)$ & 21.6 & 22.8 & 26.4 \\
\hline
\end{tabular}


By increasing $\mathrm{pH}$, initial metal concentrations are expected to decrease and higher $\mathrm{pH}$ values to appear within a shorter period of time. However, in the present case, increasing $\mathrm{pH}$ to 7 did not help improving metals' removal efficacy. Cr removal percentage was limited to $25 \%$ and $\mathrm{Ni}$ to almost $50 \%$, hence $\mathrm{Cr}$ mechanism was interrupted. This occurred because $\mathrm{Cr}$ reduction was restrained and the $\mathrm{Cr}(\mathrm{VI})$ did not convert into $\mathrm{Cr}(\mathrm{III})$ and precipitate, in turn. Consequently, a pH value around 5 is considered to be the optimal.

\section{Profile of energy consumption}

Energy consumption was calculated according to the following formula:

$$
\mathrm{E}=\frac{\mathrm{U} \cdot \mathrm{t} \cdot \mathrm{I}}{\mathrm{V}}
$$

where $U$ was the required voltage $(V)$, I the applied current $(A), t$ the required $E C$ time $(h)$ and $V$ the volume $(\mathrm{L})$. It is directly proportional to the electrical current and voltage used and experiments that were performed under higher currents required higher energy. As the results in Tables 1, 2 and 3 indicate, energy consumption was kept at the same order of magnitude for all EC experiments. A general observation that can be reported is that higher initial metal concentrations led to higher energy expenditure (see Table 1). This can be mainly attributed to elevated conductivities that accompany high metal concentrations, thus favouring electrical current and resulting, finally, in an increase in energy consumption. Another trend that was also observed is that at low $\mathrm{pH}$ values, where low voltage is needed because of the higher conductivity, energy expenditure was kept at lower levels but still in the same order of magnitude for all three EC runs (see Table 3 ).

\section{CONCLUSIONS}

This work concentrated on investigating the efficiency and behaviour of $\mathrm{Al}$ and Fe electrodes in the $\mathrm{EC}$ treatment of $\mathrm{Cr}$ and $\mathrm{Ni}$, existing both separately and simultaneously in model solutions. Several parameters were examined, such as initial metal concentration, iron and aluminum electrode combination, applied current and initial pH of the solution for a treatment period of 180 minutes.

Heavy metals exhibited faster removal rates at higher concentrations, but lower residual concentrations were obtained at lower initial concentrations. Hexavalent chromium was removed sufficiently by using iron electrodes at high current supply via its reduction to trivalent chromium. Approximately $50 \%$ of the total chromium removal was achieved, out of which $65 \%$ was hexavalent, with an initial concentration of $100 \mathrm{mg} \mathrm{l}^{-1}$, initial $\mathrm{pH} 5$ and a current of $0.8 \mathrm{~A}$. Residual concentration of hexavalent chromium, in this case, was $41 \mathrm{mg} \mathrm{l}^{-1}$. Nickel, on the other hand, was removed instantly as hydroxide precipitates, with the use of aluminum electrodes, again at high current values. The best result achieved for nickel was $90 \%$ removal at an initial concentration of $100 \mathrm{mg} \mathrm{I}^{-1}$, initial $\mathrm{pH} 5$ and a 1.0 A current (residual concentration in this experiment was $11 \mathrm{mg} \mathrm{I}^{-1}$ ).

In the case of the simultaneous existence of both metals in the model solution, $\left(100 \mathrm{mg} \mathrm{I}^{-1} \mathrm{Cr}\right.$ and $100 \mathrm{mg} \mathrm{l}^{-1} \mathrm{Ni}$ ) with the use of iron electrodes, $76 \%$ of $\mathrm{Cr}$ and $82 \%$ of $\mathrm{Ni}$ were removed, leaving $30 \mathrm{mg} \mathrm{I}^{-1}$ of $\mathrm{Cr}$ and $17 \mathrm{mg} \mathrm{I}^{-1}$ of $\mathrm{Ni}$ untreated (the lowest residual concentration reached). Optimum $\mathrm{pH}$ value for the electrocoagulation system was found to be around 4.5-5, which was the $\mathrm{pH}$ value of the heavy metals' solution without any adjustment. This can be attributed to the removal mechanisms and the ability of the hydroxides to precipitate at those $\mathrm{pH}$ values. Meanwhile, as the concentration of the heavy metal decreased during electrocoagulation process, $\mathrm{pH}$ value increased, due to the hydroxide ions formed at the cathode. The sacrificial anode's electrode dissolution experimental values followed Faraday's law.

\section{REFERENCES}

1. Aber S., Amani-Ghadim A.R. and Mirzajani V. (2009) Removal of $\mathrm{Cr}(\mathrm{VI})$ from polluted solutions by electrocoagulation: Modeling of experimental results using artificial neural network, J. Hazard Mater, 171(1-3), 484-490.

2. Akbal F. and Camci S. (2011) Copper, chromium and nickel removal from metal plating wastewater by electrocoagulation, Desalination, 269(1-3), 214-222.

3. Akbal F. and Camci S. (2012) Treatment of metal plating wastewater by electrocoagulation, Environ Prog Sustain Energy, 31(3), 340-350. 
4. Arroyo M.G., Perez-Herranz V., Montanes M.T., Garcia-Anton J. and Guinon J.L. (2009) Effect of pH and chloride concentration on the removal of hexavalent chromium in a batch electrocoagulation reactor, J. Hazard Mater, 169(1-3), 1127-1133.

5. Arsand D.R., Kummerer K. and Martins A.F. (2012) Removal of dexamethasone from aqueous solution and hospital wastewater by electrocoagulation, Sci Total Environ, 443(C), 351-357.

6. Bani-Melhem K. and Smith E. (2012) Grey water treatment by a continuous process of an electrocoagulation unit and a submerged membrane bioreactor system, J. Chem Eng., (198-199), 201-210.

7. Barrera-Díaz C., Palomar-Pardavé M., Romero-Romo M. and Martínez S. (2003) Chemical and electrochemical considerations on the removal process of hexavalent chromium from aqueous media, J. Appl Electrochem, 33(1), 61-71.

8. Bhatti M.S., Reddy A.S. and Thukral A.K. (2009) Electrocoagulation removal of $\mathrm{Cr}(\mathrm{VI})$ from simulated wastewater using response surface methodology, J. Hazard Mater, 172(2-3), 839-846.

9. Cataldo Hernández M., Barletta L., Dogliotti M.B., Russo N., Fino D. and Spinelli P. (2012) Heavy metal removal by means of electrocoagulation using aluminum electrodes for drinking water purification, J. Appl Electrochem, 42(9), 809-817.

10. Chen G., Chen X. and Yue P.L. (2000) Electrocoagulation and electroflotation of restaurant wastewater, J. Environ Eng., 126(9), 858-863.

11. Do J.-S. and Chen M.-L. (1994) Decolourization of dye-containing solutions by electrocoagulation, J. Appl Electrochem, 24(8), 785-790.

12. Edris B., Kamal Aldin Ownagh K.A. and Mahvi A.H. (2012) Application of electrocoagulation process using iron and aluminum electrodes for fuoride removal from aqueous environment, E-Journal of Chemistry, 9(4), 2297-2308.

13. Epa U.S. (1998) IRIS Toxicological Review of Hexavalent Chromium, U.S. Environmental Protection Agency, CAS No. 18540-29-9.

14. Fu F. and Wang Q. (2011) Removal of heavy metal ions from wastewaters: A review, J. Environ Manage, 92(3), 407-418.

15. Gao P., Chen X., Shen F. and Chen G. (2005) Removal of chromium(VI) from wastewater by combined electrocoagulation-electroflotation without a filter, Sep Purif Technol., 43(2), 117-123.

16. Gerberding J.L. (2005) Toxicological Profile for Nickel, Atlanta, Georgia, Agency for Toxic Substances and Disease Registry, Division of Toxicology.

17. Hanay O. and Hasar H. (2011) Effect of anions on removing $\mathrm{Cu}^{2+}, \mathrm{Mn}^{2+}$ and $\mathrm{Zn}^{2+}$ in electrocoagulation process using aluminum electrodes, J. Hazard Mater, 189(1-2), 572-576.

18. Heidmann I. and Calmano W. (2008a) Removal of $\mathrm{Cr}(\mathrm{VI})$ from model wastewaters by electrocoagulation with Fe electrodes, Sep Purif Technol., 61(1), 15-21.

19. Heidmann I. and Calmano W. (2008b) Removal of $\mathrm{Zn}(\mathrm{II}), \mathrm{Cu}(\mathrm{II}), \mathrm{Ni}(\mathrm{II}), \mathrm{Ag}(\mathrm{I})$ and $\mathrm{Cr}(\mathrm{VI})$ present in aqueous solutions by aluminium electrocoagulation, J. Hazard Mater, 152(3), 934-941.

20. Heidmann I. and Calmano W., (2010) Removal of $\mathrm{Ni}, \mathrm{Cu}$ and $\mathrm{Cr}$ from a galvanic wastewater in an electrocoagulation system with Fe- and Al-electrodes, Sep Purif Technol., 71(3), 308-314.

21. Holt P.K., Barton G.W., Wark M. and Mitchell C.A. (2002) A quantitative comparison between chemical dosing and electrocoagulation, Colloids Surf., A, 211(2-3), 233-248.

22. Keshmirizadeh E., Yousefi S. and Rofouei M.K. (2011) An investigation on the new operational parameter effective in $\mathrm{Cr}(\mathrm{VI})$ removal efficiency: a study on electrocoagulation by alternating pulse current, J. Hazard Mater., 190(1-3), 119-124.

23. Lin S.H. and Peng C.F. (1994) Treatment of textile wastewater by electrochemical method, Water Res., 28(2), 277-282.

24. Módenes A.N., Espinoza-Quiñones F.R., Borba F.H. and Manenti D.R. (2012) Performance evaluation of an integrated photo-Fenton - Electrocoagulation process applied to pollutant removal from tannery effluent in batch system, J. Chem Eng., 197, 1-9.

25. Mohora E., Roncevic S., Dalmacija B., Agbaba J., Watson M., Karlovic E. and Dalmacija M. (2012) Removal of natural organic matter and arsenic from water by electrocoagulation/flotation continuous flow reactor,J. Hazard Mater, 235-236, 257-264.

26. Mollah M.Y., Morkovsky P., Gomes J.A., Kesmez M., Parga J. and Cocke D.L. (2004) Fundamentals, present and future perspectives of electrocoagulation, J. Hazard Mater, 114(1-3), 199-210.

27. Öğütveren Ü.B. and Koparal S. (1997) Electrocoagulation for oil-water emulsion treatment, J. Environ Scie Health A Environ Sci Eng Toxicol., 32(9-10), 2507- 2520. 
28. Thella K., Verma B., Srivastava V.C. and Srivastava K.K. (2008) Electrocoagulation study for the removal of arsenic and chromium from aqueous solution, J. Environ Sci Health A Tox Hazard Subst Environ Eng., 43(5), 554-562.

29. Vasudevan S., Lakshmi J. and Sozhan G. (2011) Studies on the Al-Zn-In-alloy as anode material for the removal of chromium from drinking water in electrocoagulation process, Desalination, 275(1-3), 260-268.

30. Zongo I., Leclerc J.-P., Maïga H.A., Wéthé J. and Lapicque F. (2009) Removal of hexavalent chromium from industrial wastewater by electrocoagulation: A comprehensive comparison of aluminium and iron electrodes, Sep Purif Technol., 66(1), 159-166. 